\title{
Evaluation of African Maize Cultivars for Resistance to Fall Armyworm Spodoptera frugiperda (J. E. Smith) (Lepidoptera: Noctuidae) Larvae
}

\author{
Xavier Chiriboga Morales 1,*(i), Amanuel Tamiru ${ }^{1}\left(\mathbb{D}\right.$, Islam S. Sobhy ${ }^{2,3} \mathbb{D}$, Toby J. A. Bruce ${ }^{2}$, \\ Charles A. O. Midega ${ }^{1,4}$ and Zeyaur Khan ${ }^{1}$
}

1 International Centre of Insect Physiology and Ecology (icipe), P.O. Box 30772-00100, Nairobi, Kenya; atamiru@icipe.org (A.T.); cmidega@povertyhealth.org (C.A.O.M.); zkhan@icipe.org (Z.K.)

2 Centre for Applied Entomology and Parasitology, School of Life Sciences, Keele University, Keele, Staffordshire ST5 5BG, UK; i.sobhy@keele.ac.uk (I.S.S.); t.j.a.bruce@keele.ac.uk (T.J.A.B.)

3 Department of Plant Protection, Suez Canal University, Ismailia 41552, Egypt

4 Unit for Environmental Sciences and Management, North-West University, Potchefstroom 2520, South Africa

* Correspondence: xchiriboga@icipe.org

Citation: Chiriboga Morales, X.; Tamiru, A.; Sobhy, I.S.; Bruce, T.J.A.; Midega, C.A.O.; Khan, Z. Evaluation of African Maize Cultivars for Resistance to Fall Armyworm Spodoptera frugiperda (J. E. Smith) (Lepidoptera: Noctuidae) Larvae. Plants 2021, 10, 392. https://doi.org/ $10.3390 /$ plants10020392

Academic Editor: Michael J. Stout Received: 12 January 2021

Accepted: 3 February 2021

Published: 18 February 2021

Publisher's Note: MDPI stays neutral with regard to jurisdictional claims in published maps and institutional affiliations.

Copyright: (C) 2021 by the authors Licensee MDPI, Basel, Switzerland. This article is an open access article distributed under the terms and conditions of the Creative Commons Attribution (CC BY) license (https:/ / creativecommons.org/licenses/by/ $4.0 /)$.

\begin{abstract}
The fall armyworm (FAW) has recently invaded and become an important pest of maize in Africa causing yield losses reaching up to a third of maize annual production. The present study evaluated different aspects of resistance of six maize cultivars, cropped by farmers in Kenya, to FAW larvae feeding under laboratory and field conditions. We assessed the arrestment and feeding of FAW neonate larvae in no-choice and choice experiments, development of larvae-pupae, food assimilation under laboratory conditions and plant damage in a field experiment. We did not find complete resistance to FAW feeding in the evaluated maize cultivars, but we detected differences in acceptance and preference when FAW larvae were given a choice between certain cultivars. Moreover, the smallest pupal weight and the lowest growth index were found on 'SC Duma 43' leaves, which suggests an effect of antibiosis of this maize hybrid against FAW larvae. In contrast, the highest growth index was recorded on 'Rachar' and the greatest pupal weight was found on 'Nyamula' and 'Rachar'. The density of trichomes on the leaves of these maize cultivars seems not to be directly related to the preference of neonates for feeding. Plant damage scores were not statistically different between cultivars in the field neither under natural nor artificial infestation. However, plant damage scores in 'Nyamula' and 'Jowi' tended to be lower in the two last samplings of the season compared to the two initial samplings under artificial infestation. Our study provides insight into FAW larval preferences and performance on some African maize cultivars, showing that there are differences between cultivars in these variables; but high levels of resistance to larvae feeding were not found.
\end{abstract}

Keywords: fall armyworm; larval feeding; maize; cultivars; host-plant resistance; Africa

\section{Introduction}

Fall armyworm (FAW) Spodoptera frugiperda (J. E. Smith) (Lepidoptera: Noctuidae) is a polyphagous insect pest that had been confined to the tropical and subtropical Americas until it was reported first in Nigeria, Benin, Togo, and Sao Tome and Principe in 2016 [1]. FAW invasion has become the biggest threat to maize production in sub-Saharan Africa due to its rapid spread to almost all countries in the region and associated crop damage [2]. The pest has further spread, during the last two years to India [3], Yemen, Sri Lanka, Bangladesh, Myanmar, Thailand, China [4-6], Indonesia, Laos, Malaysia, Vietnam, Egypt, the Republic of Korea, and Japan [7] and the most recent invasions has been detected in Australia, Mauritania, and East Timor [8]. The impact of FAW on maize yield in Africa has been severe [9]. Based on farmers' perceptions, some authors have estimated the loss of maize yields between 22 and $67 \%$ in Ghana and Zambia [2], and between 32\% and 47\% in Ethiopia and Kenya [10]; resulting in millions of US dollars in losses. Baudron et al. have 
estimated that, with an incidence of FAW ranging between 32 and $48 \%$, the impact of FAW on maize yield is around $11.5 \%$ [9].

Host plant resistance is an important component of integrated pest management [11], thus finding any maize cultivars that are FAW-resistant could be a key aspect for developing sustainable strategies to control this voracious insect and minimize yield losses in a context of low input agriculture in developing countries [12]. Screening for FAW resistant maize germplasm has been carried out exhaustively in the Americas since the 1950s [13]; however, maize germplasm locally adapted to the new geographical distribution of FAW in Africa still requires investigation. Currently, several maize cultivars from CIMMYT collections have been assessed for resistance to FAW in Kenya [14]. However, maize landraces that are the most preferred and are grown by smallholder farmers in Kenya have not been evaluated for resistance to FAW. These open pollinated varieties (OPVs) have been grown by smallholder farmers over generations because they are perceived to be drought and pest tolerant, low costs of acquiring seeds, and give reasonable yields under marginal environmental conditions without application of fertilizers and pesticides [15]. Indeed, studies have reported that they are less affected by the parasitic striga weed, Striga hermonthica Benth. (Orobanchaceae) [16], and have superior defense against cereal stemborers [17]. Our study evaluates a number of these OPVs for resistance to feeding by FAW larvae comparing to locally grown hybrids. We hypothesized that FAW larval arrestment (i.e., behavior which makes the insect restrict its movement to a small area), feeding, development and plant damage vary depending on maize cultivar, measures that can be used as a proxy for resistance to FAW. We used laboratory experiments to assess the arrestment, feeding, development and food assimilation of FAW larvae and a field experiment to estimate FAW damage to maize plants. We also measured the density of trichomes on maize leaves as a possible explanation of any variation observed in acceptance and preference by FAW larvae. We discuss our findings in terms of host-plant selection behavior (selection, acceptance, and preference), features of direct resistance of maize cultivars to larvae feeding and the nutritional value of maize cultivars for larvae. The integration of maize resistance with other strategies of sustainable FAW management are also discussed within updated approaches of host-plant resistance $[18,19]$.

\section{Results}

\subsection{Arrestment/Dispersal and Feeding Experiments in No-Choice Tests}

We found significant differences $\left(\mathrm{F}_{5,54}=11.24, p<0.001\right)$ in arrestment behavior of FAW neonate larvae on leaf cuts of different maize cultivars after $24 \mathrm{~h}$ in no-choice experiments. Larval arrestment was significantly higher in the landrace 'Jowi' compared to the hybrids 'Pioneer 30G19', 'WH507' and 'SC Duma 43', and the landrace 'Rachar' (Figure 1a). However, larvae consumed significantly more leaf area on the hybrids 'WH507' and 'SC Duma $43^{\prime}\left(\mathrm{F}_{5,54}=12.46, p<0.001\right)$ than on other cultivars (Figure $\left.2 \mathrm{a}\right)$. In contrast, after $48 \mathrm{~h}$, there were no significant differences between the maize cultivars in terms of arrestment $\left(\mathrm{F}_{5,54}=2.15, p>0.05\right)$ and consumed leaf area $\left(\mathrm{F}_{5,54}=1.18, p>0.05\right)$ (Figures $1 \mathrm{~b}$ and $\left.2 \mathrm{~b}\right)$.

\subsection{Orientation/Settling and Feeding in Two-Choice Experiments}

We found significant differences for orientation and settling of FAW neonate larvae on leaf cuts of some choice-combinations of maize cultivars after $24 \mathrm{~h}$. Settling of larvae was significantly higher on the landrace 'Rachar' than on the hybrids 'SC Duma 43' $\left(x^{2}=9.7\right.$, $d f=1, p=0.001)$ and 'Pioneer 30G19' $\left(x^{2}=13.7, d f=1, p=0.0002\right)$. On the other hand, significantly less larvae settled on the landrace 'Nyamula' than on the hybrid 'WH507' $\left(x^{2}=5.5, d f=1, p=0.01\right)$, and on the landrace 'Jowi' than on 'Nyamula' $\left(x^{2}=6.9, d f=1\right.$, $p=0.008$ ) (Figure 3a). 


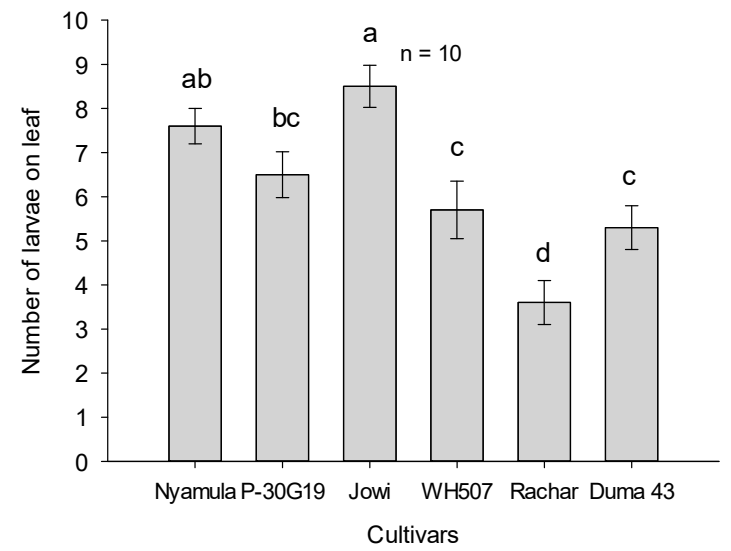

(a)

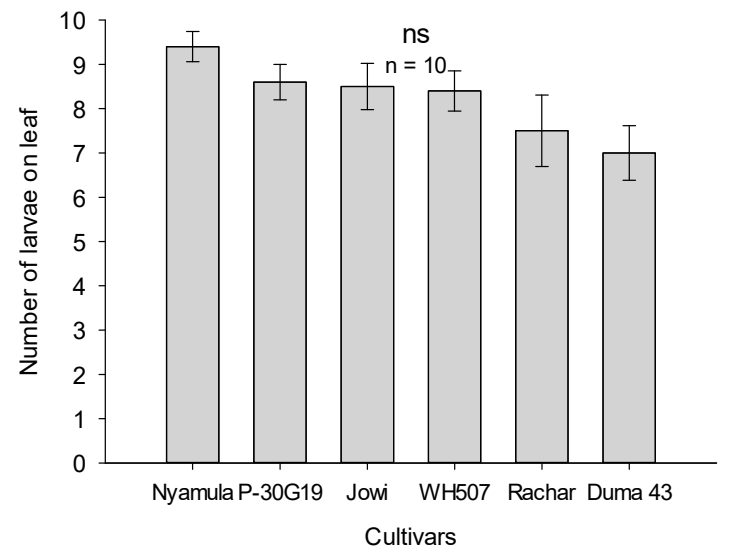

(b)

Figure 1. Number of fall armyworm (FAW) larvae (arrestment) on leaf cuts of maize cultivars (average $\pm S E M ; n=10)$ in a no-choice experiment after $24 \mathrm{~h}(\mathbf{a})$ and after $48 \mathrm{~h}(\mathbf{b})$. Different letters represent significant differences based on Tukey HSD test $(5 \%)$ and (ns) represents no significant differences.

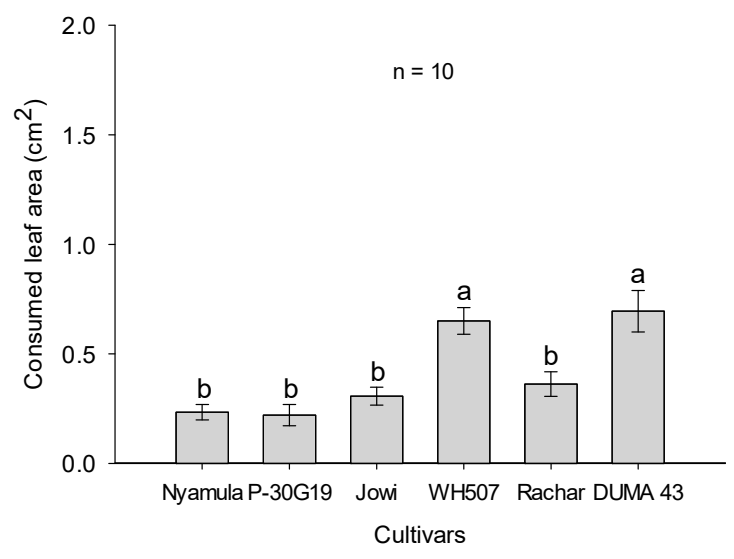

(a)

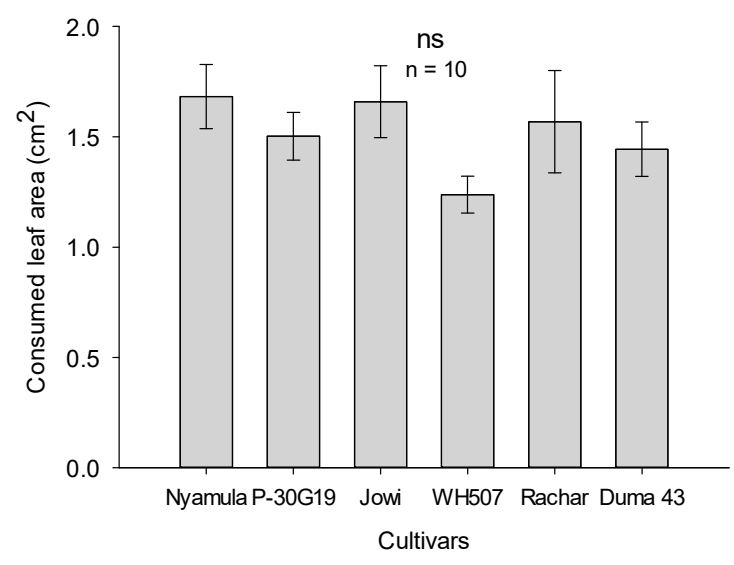

(b)

Figure 2. Consumed leaf area $\left(\mathrm{cm}^{2}\right.$; average $\left.\pm S E M ; n=10\right)$ in maize cultivars by FAW neonate larvae in a no-choice experiment after $24 \mathrm{~h}(\mathbf{a})$ and $48 \mathrm{~h}(\mathbf{b})$. Different letters represent significant differences based on Tukey HSD test (5\%) and (ns) represents no significant differences.

We also found significant differences for settling of larvae in some combinations of maize cultivars after $48 \mathrm{~h}$. The number of larvae that settled on 'Nyamula' landrace was significantly higher than the number of larvae that settled on the hybrid 'Pioneer 30G19' $\left(x^{2}=6.9, d f=1, p=0.008\right)$, and on the landrace 'Jowi' $\left(x^{2}=5.9, d f=1, p=0.01\right)$. Moreover, significantly higher number of larvae settled on leaf cuts of 'Jowi' than on leaf cuts of 'WH507' $\left(x^{2}=5.3, d f=1, p=0.02\right)$ (Figure $\left.3 b\right)$. The preference for 'Nyamula' over 'Jowi' was also observed at $24 \mathrm{~h}$ but other choices varied more between these two time points.

When assessing feeding after $24 \mathrm{~h}$, we also found differences in consumed leaf area for some combinations. Larvae consumed significantly more leaf area on the landrace 'Jowi' than in the hybrid 'Pioneer 30G19' $(t=3.5, d f=5, p=0.01)$. Similarly, larvae consumed more leaf area on the landrace 'Rachar' than on the hybrid 'Pioneer 30G19' ( $t=4.9, d f=5$, $p=0.004)$, and on the hybrid 'WH507' than on the landrace 'Nyamula' $(t=3.2, d f=5$, $p=0.02$ ) (Figure $4 \mathrm{a})$. 


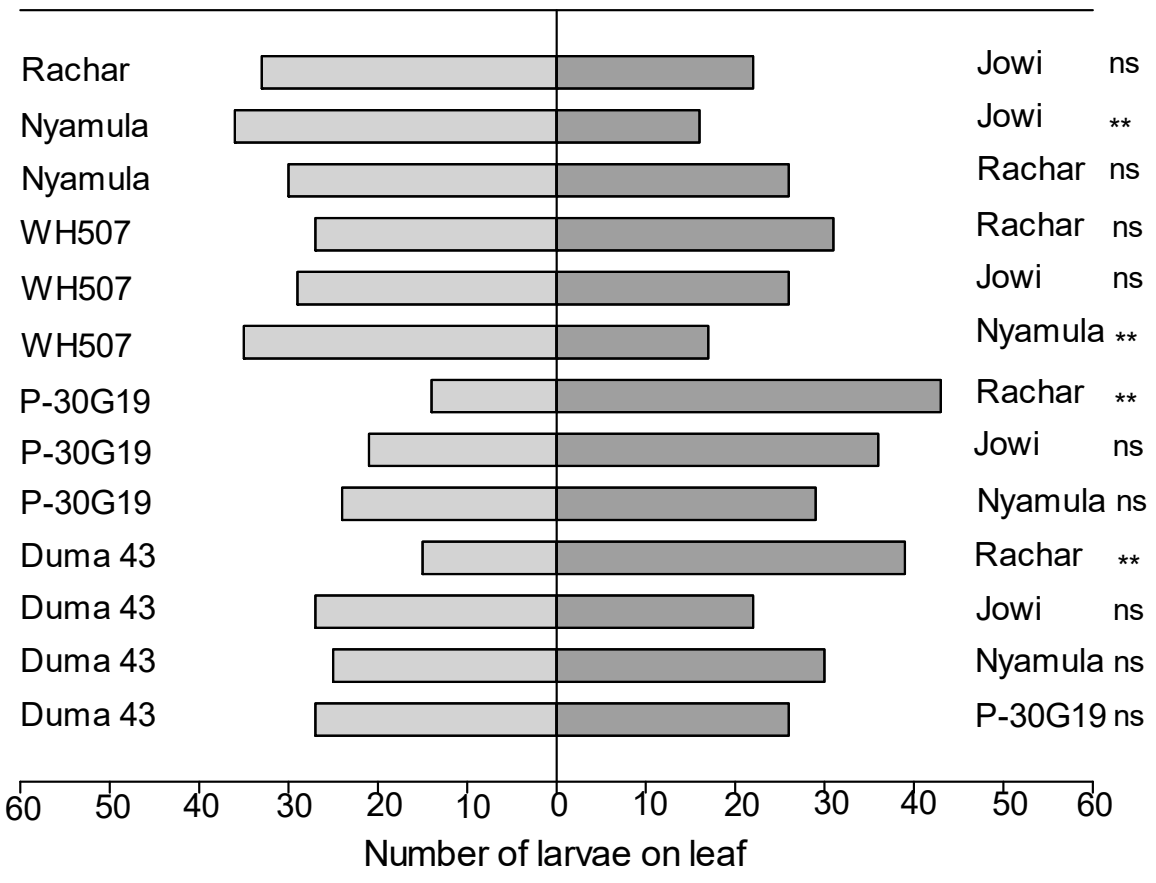

(a)

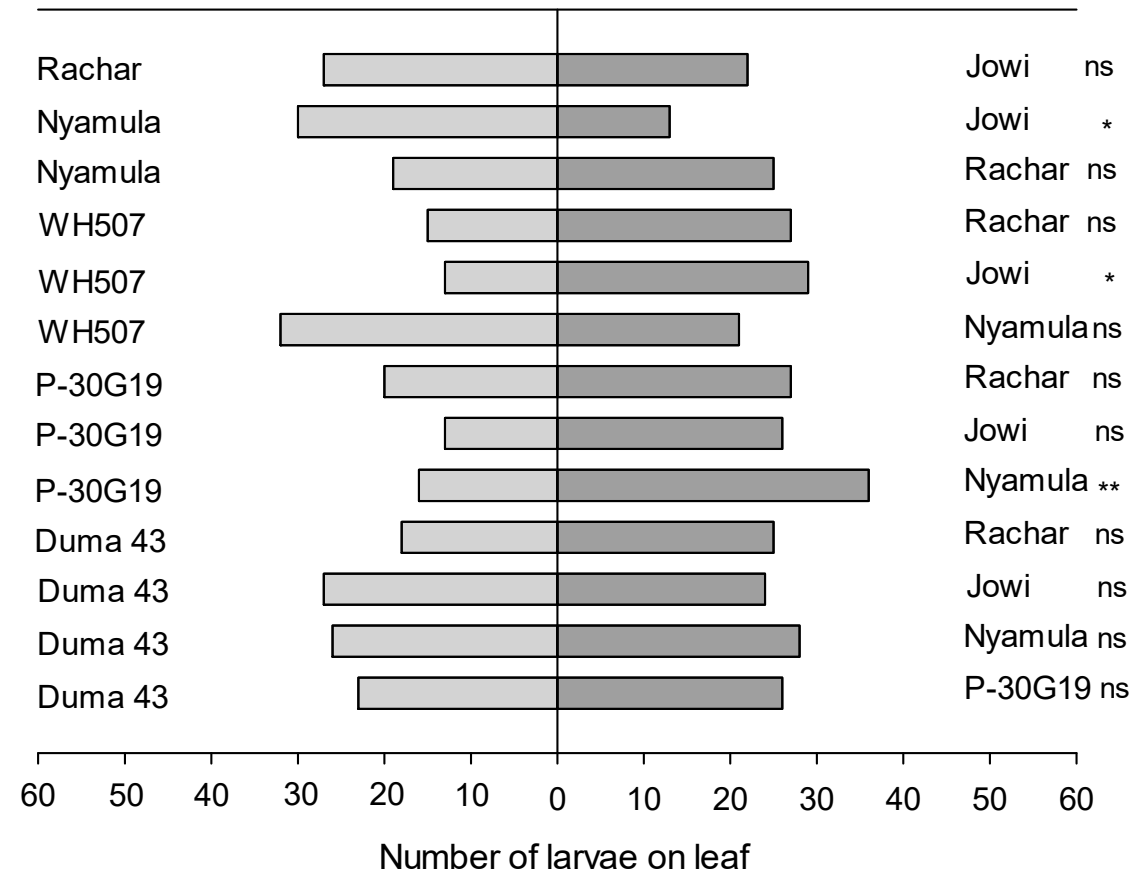

(b)

Figure 3. Number of FAW larvae that settled on leaf cuts of different combinations of maize cultivars in a two-choice-experiment (a) after $24 \mathrm{~h}$ and (b) after $48 \mathrm{~h}$. Asterisks represent significant differences $\left({ }^{*} p \leq 0.05 ;{ }^{* *} p \leq 0.01\right)$ and (ns) represents no significant difference between cultivars $(\mathrm{n}=6)$, based on Chi-square test. 


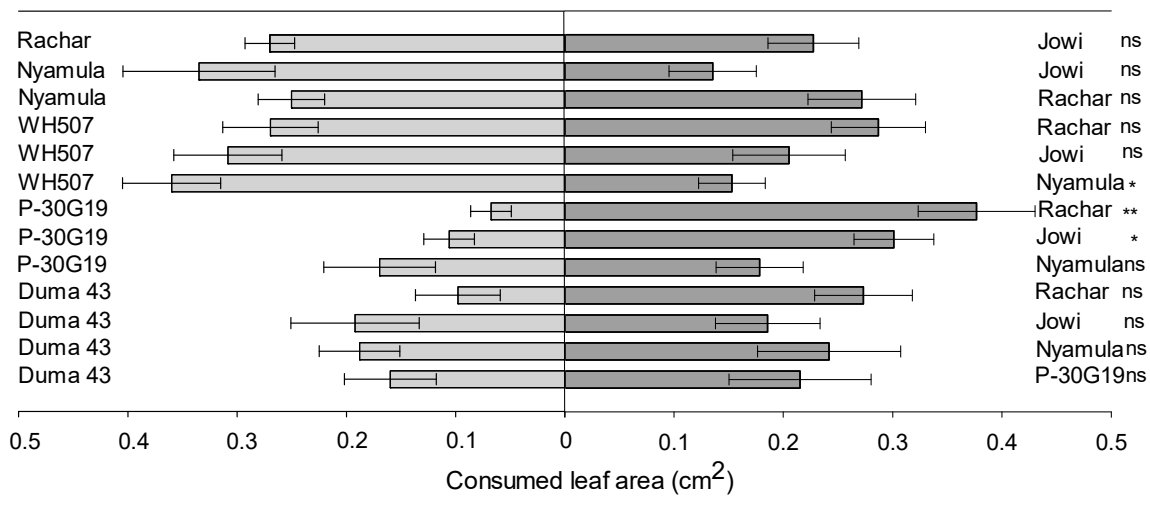

(a)

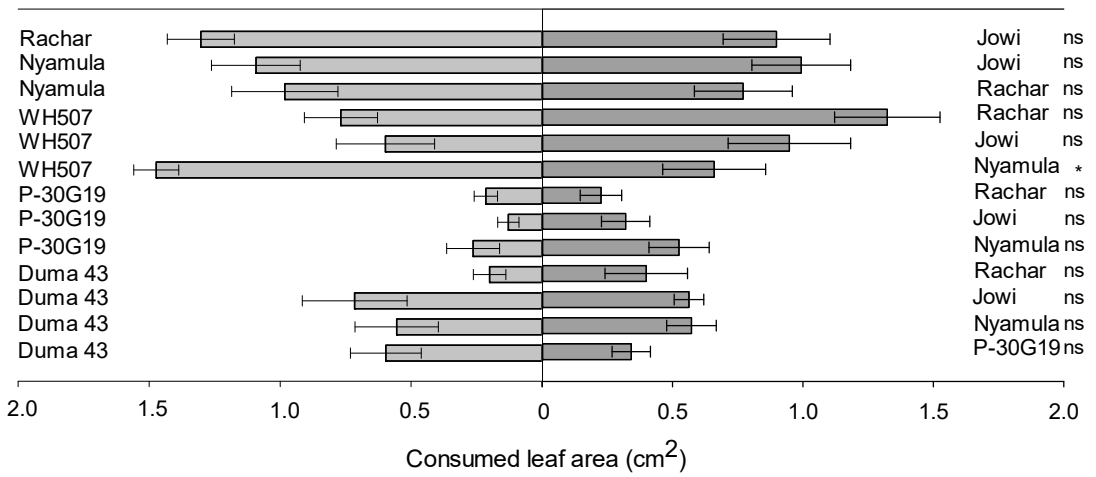

(b)

Figure 4. Consumed leaf area $\left(\mathrm{cm}^{2}\right.$; average $\left.\pm S E M ; n=6\right)$ of different combinations of maize cultivars by FAW neonate larvae in a two-choice experiment (a) after $24 \mathrm{~h}$ and (b) after $48 \mathrm{~h}$ of feeding. Asterisks represent significant differences $\left({ }^{*} p \leq 0.05 ;{ }^{* *} p \leq 0.01\right)$ and (ns) represents no significant differences, based on Paired $t$-test.

In terms of feeding, after $48 \mathrm{~h}$, a significantly higher leaf consumption was found in the hybrid 'WH507' compared to the landrace 'Nyamula' $(t=3.24, d f=5, p=0.02)$ (Figure 4b).

\subsection{Larval-Pupal Development Experiment}

We found a significant effect of the maize cultivar $\left(\mathrm{F}_{5,34}=4.46, p \leq 0.05\right)$ and developmental time $\left(\mathrm{F}_{1,34}=36.59, p \leq 0.001\right)$ on larval weight. The effect of the interaction between cultivar and time $\left(\mathrm{F}_{5,34}=2.65, p \leq 0.05\right)$ was also significant. At day nine, larval weight was significantly higher in the maize cultivars 'Nyamula', 'Rachar', and 'Pioneer 30G19' compared to 'SC Duma 43'. However, we did not find significant differences in the weight of larvae developed on maize cultivars at day twelve (Figure 5). 


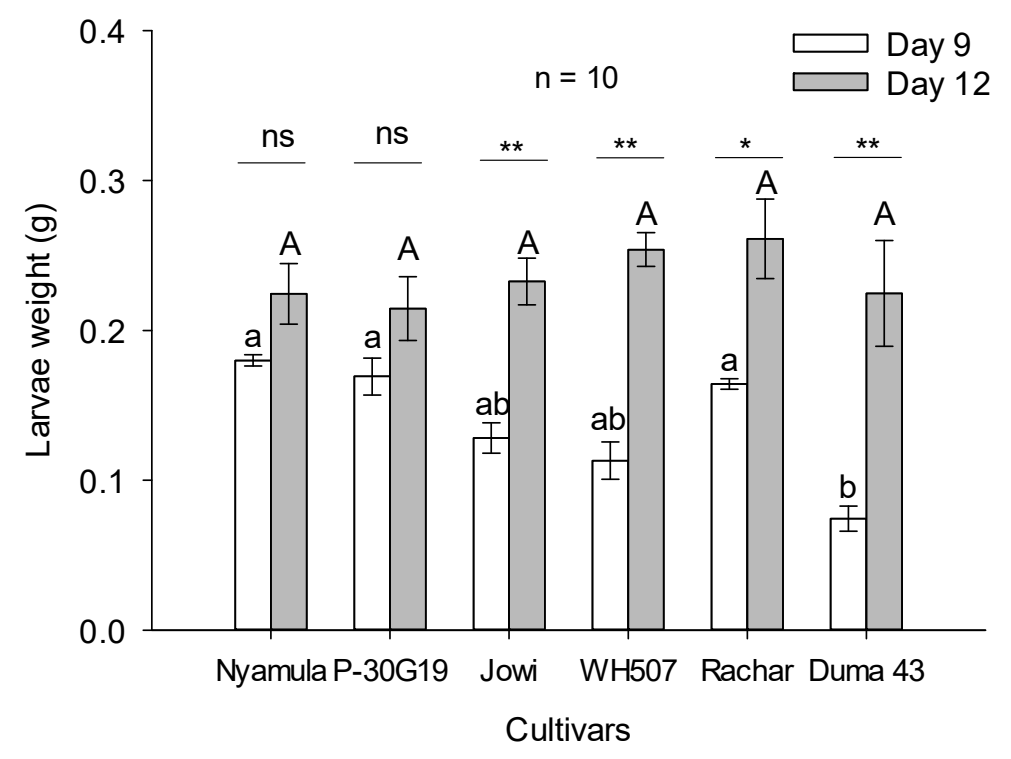

Figure 5. Larval weight (mean $\pm \mathrm{SEM} ; \mathrm{n}=10$ ) of FAW developed on different maize cultivars at two time points. Asterisks represent significant differences $\left({ }^{*} p \leq 0.05 ;{ }^{* *} p \leq 0.01\right)$ between time-points and (ns) represents no significant differences between time-points. Lowercase different letters represent significant differences between maize cultivars within Day 9. Uppercase letters represent no significant differences between cultivars within Day 12, based on Holm-Sidak method (Two-way ANOVA).

Furthermore, we found significant differences in the weight of FAW pupae yielded from those larvae developed on different maize cultivars $\left(\mathrm{F}_{6,27}=5.43, p \leq 0.001\right)$. Specifically, pupal weight was significantly higher in the landraces 'Nyamula' and 'Rachar' compared to the hybrid 'SC Duma 43' (Figure 6). Differences in pupal weight were similar to differences in larval weight observed at day 9 .

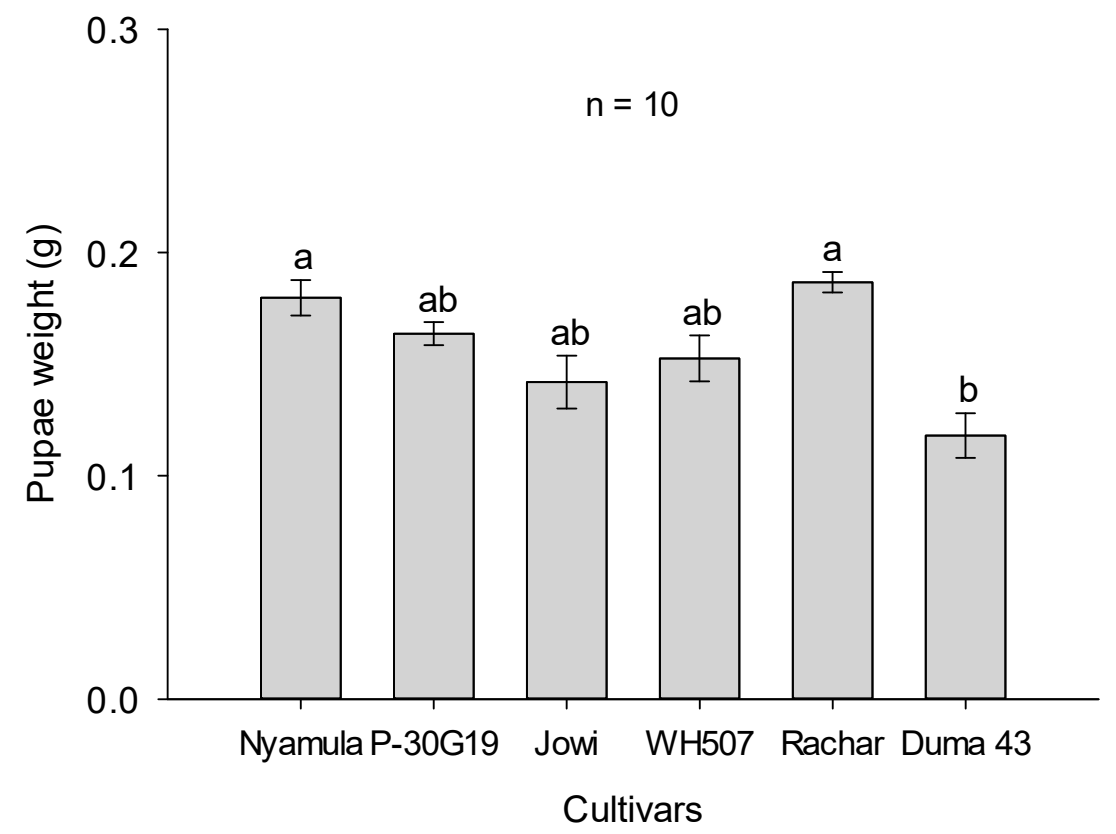

Figure 6. Pupal weight (mean $\pm S E M ; n=10$ ) of FAW when their larval stage developed on several maize cultivars at day 15. Different letters represent significant differences based on Tukey HSD test $(5 \%)$. 
The percentage of accumulated mortality was $50 \%$ for FAW larvae developed on the landrace 'Nyamula' and on the hybrid 'SC Duma 43'; meanwhile, mortality was 30\% and $20 \%$ for larvae developed on the landraces 'Jowi' and 'Rachar', respectively (Table 1). Furthermore, the growth index (calculated as the ratio between percentage of pupation and larval period) was highest for larvae developed on 'Rachar' and lowest for larvae developed on 'SC Duma 43' (Table 1).

Table 1. Mortality, pupation, larval period, and growth index of FAW larvae fed on six maize cultivars.

\begin{tabular}{|c|c|c|c|c|}
\hline Maize Cultivar & Percentage of Mortality (\%) & Percentage of Pupation (\%) & Mean Larval Period (Days) & Growth Index \\
\hline Nyamula & 50 & 50 & 15.0 & 3.33 \\
\hline Pioneer 30G19 & 30 & 70 & 15.0 & 4.67 \\
\hline Jowi & 30 & 70 & 15.9 & 4.41 \\
\hline WH507 & 40 & 60 & 15.0 & 4.00 \\
\hline Rachar & 20 & 80 & 15.0 & 5.33 \\
\hline SC Duma 43 & 50 & 50 & 16.8 & 2.98 \\
\hline
\end{tabular}

\subsection{Food Assimilation}

The weight of assimilated food was not statistically different $(\mathrm{H}=6.51, d f=5, p=0.2)$ between maize cultivars, nor the consumed leaf weight $(\mathrm{H}=5.41$, $d f=5, p=0.3)$. Here, we show the values of both parameters in Table 2.

Table 2. Assimilated food weight (g) and consumed leaf weight (mean \pm SE) by FAW larvae fed on six maize cultivars for $24 \mathrm{~h}$.

\begin{tabular}{ccc}
\hline Maize Cultivar & Assimilated Food Weight (g) & Consumed Leaf Weight (g) \\
\hline Nyamula & $0.042 \pm 0.006$ & $0.08 \pm 0.01$ \\
\hline Pioneer 30G19 & $0.050 \pm 0.007$ & $0.08 \pm 0.01$ \\
\hline Jowi & $0.037 \pm 0.003$ & $0.11 \pm 0.01$ \\
\hline WH507 & $0.057 \pm 0.011$ & $0.10 \pm 0.03$ \\
\hline Rachar & $0.056 \pm 0.006$ & $0.07 \pm 0.01$ \\
\hline SC Duma 43 & $0.043 \pm 0.004$ & $0.08 \pm 0.02$ \\
\hline
\end{tabular}

\subsection{Leaf Trichome Density}

The number of trichomes counted in a leaf area of $0.25 \mathrm{~cm}^{2}$ was significantly different $\left(\mathrm{F}_{5,54}=19.37, p \leq 0.001\right)$ between maize cultivars. The trichomes density was significantly higher in 'Jowi' and 'Rachar' compared to the landrace 'Nyamula', and the hybrids 'WH507', 'SC Duma 43' and 'Pioneer 30G19' (Figure 7).

\subsection{Field Experiment}

Overall, we found no significant effect of maize cultivar on plant damage scores in plots under natural infestation $\left(\mathrm{F}_{5,30}=0.78, p \geq 0.05\right)$ and artificial infestation $\left(\mathrm{F}_{5,30}=2.17\right.$, $p \geq 0.05)$. Plant damage scores were neither affected by sampling-date in plots naturally infested $\left(F_{3,30}=3.89, p \geq 0.05\right)$ nor artificially infested $\left(F_{3,30}=0.47, p \geq 0.05\right)$ (Figure 8). Moreover, the effect of the interaction between cultivar and sampling was not significant under natural infestation $\left(\mathrm{F}_{15,30}=1.15, p \geq 0.05\right)$ but was significant under artificial infestation $\left(\mathrm{F}_{15,30}=2.44, p \leq 0.05\right)$. 


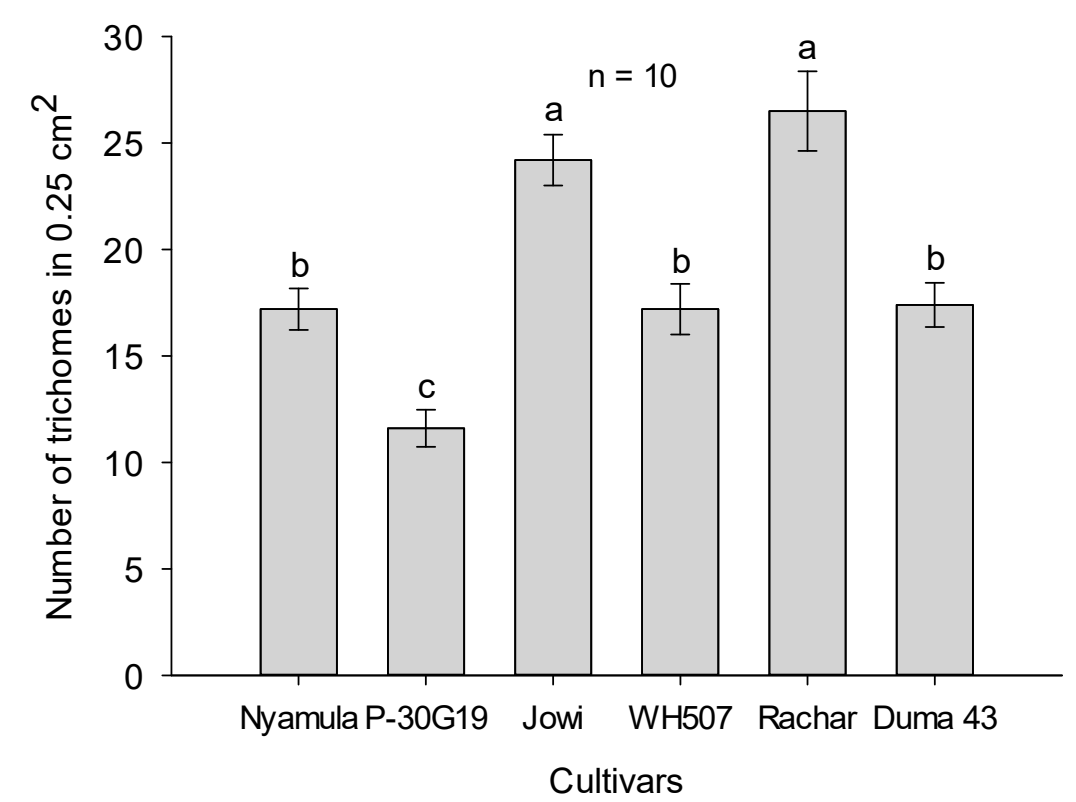

Figure 7. Number of trichomes (mean $\pm S E ; n=10$ ) in $0.25 \mathrm{~cm}^{2}$ of leaves of different maize cultivars. Different letters above bars represent significant differences between cultivars based on Tukey HSD test $(5 \%)$.

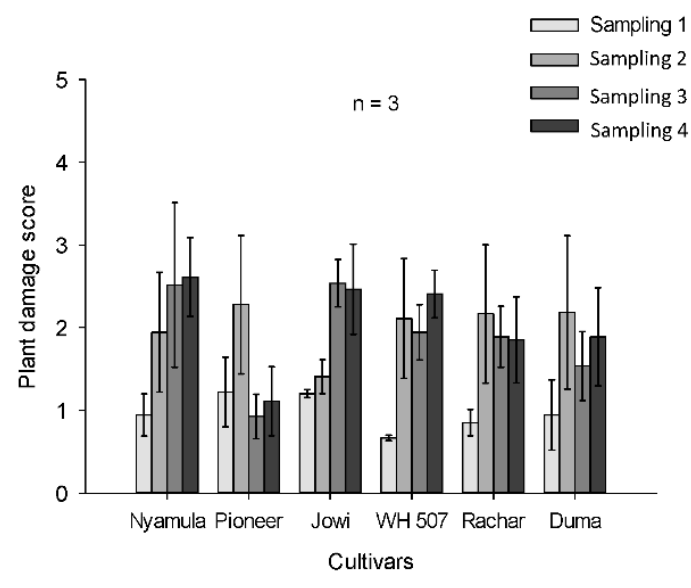

(a)

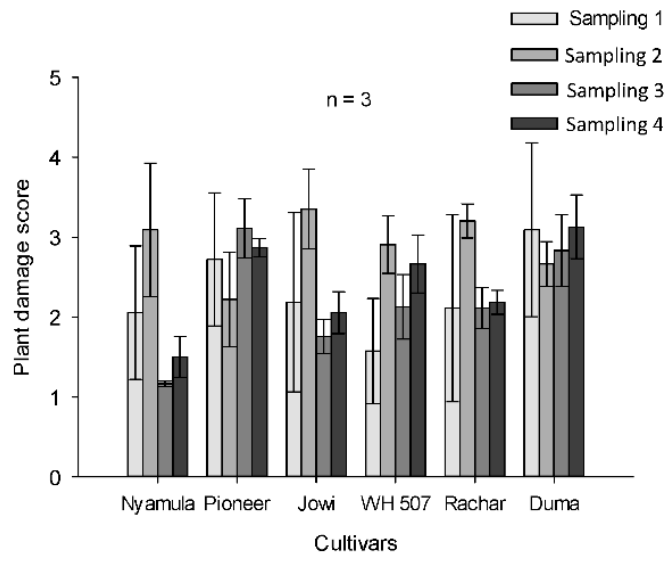

(b)

Figure 8. Plant damage scores (mean $\pm \mathrm{SE}, \mathrm{n}=3$ ) for six maize cultivars in cropping conditions across four samplings (sampling 1: 20 days after sowing, sampling 2: 40 days after sowing, sampling 3: 60 days after sowing, sampling 4: 80 days after sowing) in plots: (a) naturally infested (b) artificially infested.

\section{Discussion}

The six maize cultivars in the current study, selected on the basis of being preferred by farmers in the study area, were rigorously evaluated for several aspects of resistance to FAW feeding. None of the cultivars were found to be fully resistant to FAW larvae feeding but some differences in acceptance and preference were observed under choice test conditions. Furthermore, differences in plant suitability of maize leaves of different cultivars were found to impact FAW larval weight and pupal weight. Growth rate on the most favourable cultivars, 'Nyamula' and 'Rachar', were almost double the growth rate on the least favourable cultivar 'SC Duma $43^{\prime}$. However, there were no differences between 
cultivars in leaf weight consumed by larvae under laboratory conditions and in the field experiment no differences were found in plant damage scores.

In Petri-dish experiments, neonate larvae of FAW fed less on 'Nyamula' compared to 'SC Duma 43' and 'WH507' plants after $24 \mathrm{~h}$ under no choice conditions; however, no differences were detected between the cultivars after $48 \mathrm{~h}$ of experimentation. From the insect point of view, this might be interpreted as subtle differences perceived by the neonate larvae during the test-biting phase; however, these differences may be neglected by the insect as time passes and the need of food increases [20]. In two-choice conditions, FAW neonate larvae arrested less on 'Nyamula' compared to the hybrid 'WH507' in a period of $24 \mathrm{~h}$, and neonates fed less on 'Nyamula' compared to 'WH507' after $24 \mathrm{~h}$ and $48 \mathrm{~h}$ of experimentation. In the choice setups, selection behavior takes place, and we assume that sequential contact-testing of alternative cultivars occurs before a final selection is made by the insect. The results of the two-choice experiment indicate that FAW neonate larvae avoid feeding on 'Nyamula' leaf cuts and prefer to feed on 'WH507' leaf cuts. There was also a consistent significant preference for settling on 'Nyamula' leaf cuts over 'Jowi' which was observed both at 24 and $48 \mathrm{~h}$. Since neonates used in our experiments were one-day old, we argue that discrimination is high in these larvae [20]. We discuss possible reasons for these choices below. In our experimental context, acceptance occurs when there is sustained feeding on a leaf cut or plant; meanwhile, preference occurs when an insect, having a choice, consistently feeds more on one of the alternative plant cultivars. The process of host-plant selection and acceptance by an insect involves several behavioral steps and it is a result of the integration of internal physiological state parameters of the insect [21,22]. Initially, when an insect touches a plant, it evaluates physical and chemical plant traits which are often used for an initial behavioral decision, either to proceed or to reject the plant. In the evaluation phase insect restrict their movement to a smaller area, a behavior that is called arrestment. As a next step, the insect may damage the plant by test-biting, when the sensory information is judged positively by its nervous system, the final decision is taken, the host-plant is accepted and food intake starts [22].

Physical features of plant organs or tissues and secondary toxic metabolites can influence host-plant selection behavior and are part of the array of direct defenses of the plant; for example, trichomes, wax crystal structures, leaf thickness and toughness, and silica content may cause avoidance behavior in insects [19,22]. In maize, several characteristics have been reported to confer resistance to maize cultivars against FAW damage. For example, it was found that cuticular lipids in maize leaves play a role in FAW larvae performance. When FAW larvae fed on leaves from which cuticular lipids had been removed, weighed more and developed faster than when they fed on leaves with cuticular lipids [23]. In another study, FAW neonate larvae traveled longer distances and crawled faster on upper leaves, which have a smooth appearance, than on lower leaves, which had a dense array of wax crystals [24]. The presence of trichomes in maize leaves, in our study, did not appear to influence acceptance or preference, since 'Nyamula' leaves have a similar density of trichomes to the cultivar 'WH507', but are less preferred for feeding. In contrast, trichomes play a defensive role in some rice cultivars against chewing insects [25]. Therefore, we suggest that other physical features such as structure of cuticular compounds, leaf toughness and/or thickness may have been involved in the reduced preference for feeding on 'Nyamula' leaf cuts. Another possibility is that antifeedant or repellent chemicals were present on the latter cultivar. On the other hand, lipophilic constituents of leaf surfaces (alkenes, esters, and fatty acids) and secondary plant metabolites are known to promote test-biting and subsequent feeding in many insects [22]. For example, the noctuid Spodoptera littoralis Boisduval (Noctuidae), was found to be attracted to nine plant volatiles, proving that plant chemicals play a role in caterpillar searching behavior of host-plants [26]. On the other hand, polyphagous insects species may also be stimulated by the presence of flavonoids in their food [22]. Since acceptance of a host-plant is determined by the balance between stimulatory and inhibitory compounds, 
a thorough analysis of the compounds in the leaves tissues of these cultivars is needed to unravel their role in host-plant selection and preference.

Our findings regarding food assimilation of tested maize cultivars by third instar larvae were not statistically different. However, there was a trend with larvae consuming relatively more leaf weight of 'Jowi' plants compared to 'Nyamula', 'Pioneer 30G19', 'Rachar' and 'SC Duma 43'. The results also showed relatively less food assimilation when larvae fed on 'Jowi' leaves compared to 'Pioneer 30G19', 'WH507' and 'Rachar' leaves. The higher consumption of 'Jowi' leaves compared to the other four cultivars suggests that there may be differences in leaf composition. A previous study has demonstrated, for example, that the contents of hemicellulose and cellulose are higher in the whorls of FAW resistant maize plants compared with susceptible plants [27]. Another study has shown the role of leaf toughness in maize resistance to the European corn-borer Ostrinia nubilalis Hübner (Crambidae), finding that this character seems to be an important defense mechanism in maize across diverse groups of germplasm [28]. In addition, several factors unrelated to preference influence how much an insect eats; for example, larvae may consume more of a plant low in protein or high in protein inhibitors to compensate for its lower nutritional value [21].

Through experiments investigating insect weight gain, we show that FAW larvae (at day nine) gained more weight on 'Nyamula' and 'Rachar' leaves compared to the same instars developed on 'SC Duma 43' leaves. The same pattern was also observed for the pupal weight at day fifteen. Thus, we argue that 'SC Duma 43 ' leaves are detrimental for FAW larvae development; meanwhile, 'Nyamula' and 'Rachar' are optimal. Interestingly, larval weight was not different between cultivars at day twelve. This may be explained by the fact that the larvae that grew slower could have attained the same weight of larvae entering the prepupal stage at day twelve. Furthermore, we found differences in growth index between 'Nyamula' and 'Rachar' that are derived from differences in mortality (see Table 1). Looking together at larval mortality $(50 \%)$ and low larval-pupal weight when larvae fed 'SC Duma 43' leaves, it is clear why growth index for 'SC Duma 43' was the lowest (See Table 1). Therefore, we suggest that antibiosis against FAW larvae exist in the cultivar 'SC Duma 43'. Further investigations need to focus on analyzing factors affecting growth of FAW immature instars such as protein-carbon ratios, allelochemicals, and protease inhibitors [22,29]. Indeed, several investigations have demonstrated the effects of certain maize cultivars on larvae weight [30,31], development time and mortality of FAW larvae [32,33] when used as food. It has been shown that, for example, certain types of flavones-C-glycosides and chlorogenic acid are responsible for antibiosis activity in maize plants [11]. Other mechanisms of defense, such as maize defense genes [34] or toxic proteins [35] are triggered by FAW feeding. Characters of plants' cultivars that confer them partial resistance to insects often have effects on their biology and further success [19,36].

In terms of insect-plant interactions, the field experiment reflects two different scenarios. In artificially infested plots, FAW larvae were forced to feed on a predetermined cultivar (a no-choice situation) and maize plants were challenged to defend themselves against FAW feeding. Meanwhile, in naturally infested plots, the preference of larvae for feeding (a choice situation) takes place. Indeed, it has been proposed in a model that FAW female moths oviposit indiscriminately on different hosts but neonate larvae leave the natal hosts plants by ballooning, search and colonize suitable hosts [37]. Although we measured plant damage by FAW larvae in the field set-up with a subjective scale, our method is a standard procedure that has been used in FAW resistance research programs for many years [38]. We did not find any significant differences in plant damage scores between maize cultivars under artificial or natural infestation. However, under artificial infestation, which reflects high insect pest pressure, the landraces 'Nyamula' and 'Jowi' had lower damage scores later in the season which may suggest the potential for compensatory regrowth of these maize cultivars. Indeed, maize plants can display tolerance in response to insect attack [39]. In contrast, these cultivars under natural infestation, showed a slight increase in plant damage scores at the end of the season, which indicate that these cultivars 
may have borne successive colonization beyond the second sampling of the season. The cultivars 'WH507', 'Rachar', and 'SC Duma 43' showed stable plant damage scores across the three last samplings of the season under natural infestation. Furthermore, plant resistance evaluations in the field become complex due to the interaction of the plant with several other factors, such as location, soil type, plot area, agroecological conditions, weeding frequency, use of hedgerows, intercrops, manure, nitrogen, and year [9,40]. As Ni and his colleagues recommended, environmental conditions and predatory insects abundance should be taken into account when assessing the resistance of maize cultivars to FAW and other insects in the field [40]. Rove beetles, earwigs and spiders are important predatory insects of FAW [41,42]; however, the sampling effort of predatory arthropods in our study was not big enough to draw conclusions on this aspect (Supplementary Tables S1 and S2). Future studies should also investigate the role of indirect defense against FAW in these maize cultivars. Indeed, several studies have shown that certain maize cultivars emit volatile organic compounds (VOCs) which attract parasitoids of their insect pests, after plant damage [43], insect eggs oviposition [17], or even volatiles are produced by plants as constitutive volatiles [44] to defend themselves. In maize plants VOCs are not only important for parasitoids' attraction but also for predatory insects attraction [45].

\section{Materials and Methods}

\subsection{Plants}

For laboratory experiments, three weeks-old maize plants of six different cultivars (Nyamula, Pioneer 30G19, Jowi, WH507, Rachar, SC Duma 43) obtained from a commercial seed supplier and local Kenyan farmers were used in this study (Hybrids: Luna Agrovet Mbita, Kenya and Landraces: several Kenyan farmers). Plants were grown in plastic pots filled with agricultural soil from the Mbita farm in a screen house $\left(27 \pm 2{ }^{\circ} \mathrm{C}\right.$, $65 \pm 5 \%$ RH, 12L: 12D) at ICIPE-Thomas Odhiambo Campus (ITOC), Mbita Point (Nyanza Province, Kenya). After germination, $3.5 \mathrm{~g}$ of fertilizer (Diammonium Phosphate-DAP, Elgon Kenya) was applied in each pot. We used the leaves 6 and 7, counted according to the leaf over arching method (MAFRA's Guide to Weed Control: Field Crops, 2020) for all the experiments [46], because younger leaves are preferred by S. frugiperda for feeding [47].

\subsection{Insects}

FAW neonate larvae (one-day old) were obtained from a FAW colony reared at the ITOC insectary $\left(25 \pm 3{ }^{\circ} \mathrm{C}, 75 \pm 5 \% \mathrm{RH}\right)$ with an artificial diet (Southland Products Inc., Lake Village, AR, United States). Neonate larvae were used to perform laboratory and field experiments. Third larval instar (six-days old) was used for the food assimilation experiment.

\subsection{Arrestment-Dispersal and Feeding Experiment}

An arrestment experiment was done to evaluate the acceptance of six maize cultivars by FAW neonate larvae. The experiment was carried-out in no-choice setup. A leaf cut of $6 \mathrm{~cm}$ length (approx. $2.5 \mathrm{~cm}$ width) was placed in a Petri dish $(9 \mathrm{~cm})$ lined with a moistened filter paper. Thereafter, ten neonate larvae were released on the leaf cut, dishes were kept in dark conditions and the number of neonates remaining on the leaf cut was counted after $24 \mathrm{~h}$ and $48 \mathrm{~h}$. Ten replicates were used per each maize cultivar. Using the same set-up, we quantified the larval feeding by taking a photo of the leaf cut with a smartphone after the set time. The consumed leaf area fed was then measured automatically using the App Leafbyte (@2018 Zoe Getman-Pickering).

\subsection{Orientation-Settling and Feeding Experiment}

An orientation and settling experiment was performed in a two-choice setup to evaluate acceptance of FAW neonate larvae to the tested maize cultivars. We used combinations of two hybrids, two landraces or a hybrid with a landrace for setting the choices. Two leaf cuts of $3 \mathrm{~cm}$ length (approx. $2.5 \mathrm{~cm}$ width) were placed together. The leaf cuts were 
quadruple shaped and inclined, touching each other by two of their corners, in a Petri dish $(9 \mathrm{~cm})$ lined with a moistened filter paper. A total of ten neonate larvae were used in each Petri dish, where five neonate larvae were released up of the touching corners of the leaf cuts and five were released down of the corners, for the larvae to choose a preferred leaf cut. The dishes were kept in dark conditions and number of neonates settled on the leaf cuts was counted after $24 \mathrm{~h}$ and $48 \mathrm{~h}$. Six replicates were used per combination. Larval feeding was quantified as mentioned above. Both methods were adapted from Smith et al. [48].

\subsection{Larval-Pupal Development}

A larval development experiment was carried out in laboratory conditions $\left(25 \pm 3{ }^{\circ} \mathrm{C}\right.$, $75 \pm 5 \%$ R.H.) to evaluate the weight gain of FAW larvae that fed on different maize cultivars and thereafter pupal weight. FAW neonates were placed individually in glass vials $(2.8 \mathrm{~cm} \times 7.3 \mathrm{~cm})$ with leaf cuts of a maize cultivar. Leaf cuts were obtained from the youngest leaves of plants grown in screen-house conditions and ten replicates were used per maize cultivar. Every 3 days alive larvae were weighed and eaten leaf cuts were replaced by fresh leaf cuts in the glass vials during 15 days. Number of dead larvae and the weight of pupae were also recorded. Here we report the larval weight after 9 and 12 days. We calculated the growth index for FAW larvae fed on the six maize cultivars as the ratio between the percentage of neonate individuals that reach pupal stage and the average time needed for pupation (larval period) [48].

\subsection{Food Assimilation}

We use the procedure proposed by Smith et al. [48]. FAW larvae (3rd instar) were starved for one hour in a container with moisten paper towel. A leaf cut of $7 \mathrm{~cm}$ length was cut off the plant and weighed using a Mettler Toledo PM 460 scale (Mettler Instruments; Greiffensee, Switzerland). Leaf cuts were obtained from new fully open leaves of maize plants of the six cultivars and placed inside glass vials $(2.8 \mathrm{~cm} \times 7.3 \mathrm{~cm})$. Ten replicates were performed per cultivar. Glass vials contained a piece of moisten cotton in the bottom. The initial weight of the larvae (W1) was recorded before introducing them into the glass vial, then vials were plugged with cotton and kept in dark conditions. After $24 \mathrm{~h}$ of feeding, the weight of larvae (W2) and the remaining leaf cuts were recorded. To estimate the weight loss due to metabolism ten larvae were kept in glass vials with the wet cotton but without leaf cuts, their weight was also recorded at the start (C1) and at the end (C2) of the experiment. Leaf cuts were also kept in vials with the wet cotton but without insects to control their loss of water. The consumed weight of leaf was calculated by subtracting the final leaf weight from the initial leaf weight. The food assimilated (AF) was calculated with this formula:

$$
A F=W 1\left(\frac{C 1-C 2}{C 1}\right)+(W 2-W 1)
$$

where $A F$ is the assimilated food, $W 1$ is the initial weight of larvae, $W 2$ is the final weight of larvae, $C 1$ is the initial weight of unfed larvae and $C 2$ is the final weight of unfed larvae.

\subsection{Leaf Trichome Density}

The numbers of trichomes were counted in an area of $0.25 \mathrm{~cm}^{2}(0.5 \mathrm{~cm} \times 0.5 \mathrm{~cm})$. Samples were obtained from the intermediate position between leaf margin and midrib of the leaf lamina and halfway between proximal end and base of the leaf, from the leaves 6 and 7 of three weeks old plants. Trichomes were counted with a stereo microscope (Stemi 508 Carl Zeiss; Jena, Germany) with a magnification of $25 \times$, moistening slightly the leaf cut [49].

\subsection{Field Experiment}

A field experiment was carried out using a Randomized Complete Block design (RCBD) using three hybrids (SC Duma 43, Pioneer 30G19 and WH507) and three landraces (Jowi, Nyamula and Rachar) of maize (see field layout in Supplementary Figure S1), with 
three plot-replicates per maize cultivar in two blocks (natural infestation and artificial infestation). Maize seeds were sown at a distance of $30 \mathrm{~cm}$ between plants and $75 \mathrm{~cm}$ between rows, giving a population of 90 plants per plot. The first data recording was obtained 20 days after the sowing date, and thereafter every twenty days, four times during a season. Plant damage score was recorded, with an adapted visual scale of damage (0-9) used by van Huis [42], evaluating eighteen plants per plot. The experiment was done in the long-rain season (March-May) of 2020. In this experiment, the plots of one block were infested artificially by-hand using a camel-hair brush with ten FAW neonates per plant and the other block sustained a natural infestation by FAW. In the eighteen plants that were evaluated in the field experiments, we counted the number of predators. We report the densities of predatory insects and spiders (Supplementary data) which are known to predate on FAW larvae [42] in each maize cultivar.

\subsection{Statistics}

For no-choice experiments, data of arrestment were square root transformed since data did not have a normal distribution. Then data were analyzed with One-way ANOVA and the means were separated by Tukey HSD test (5\%). Data of consumed leaf area were analyzed with One-way ANOVA and means were separated with Tukey HSD test (5\%). For two choice experiments, data of settling were analyzed with a Chi-square Goodness of Fit test and data of leaf consumption were analyzed with a paired $t$-test. Data of larvae development were analyzed with Two-ways Repeated Measures ANOVA and pupae development were analyzed with One-way ANOVA. Data of assimilated food weight and consumed leaf weight were analyzed with Kruskai-Wallis test. Data of leaf trichome density were analyzed with One-way ANOVA and means were separated by Tukey HSD test (5\%). Plant damage scores from field data were analyzed with Two-way Repeated Measures ANOVA separately for natural and artificial infestation. All data were analyzed, transformed and checked for normality using SigmaPlot 14 (Systat Software Inc., San Jose, CA, USA).

\section{Conclusions}

Taken together these findings suggest that there is no complete resistance to FAW larval feeding in the evaluated maize cultivars. However, there are differences in acceptance and preference between certain maize cultivars. For example, when larvae are given a choice between the landrace 'Nyamula' and the hybrid 'WH507' they preferred to feed on the latter. The density of trichomes on maize leaves seems not to be associated with preferences of neonate larvae for feeding. The greatest pupal weight was recorded on the leaves of the landraces 'Nyamula' and 'Rachar'; meanwhile, the smallest pupal weight was found on the hybrid 'SC Duma 43'. Moreover, the lowest growth index was observed on 'SC Duma 43'. Therefore, our findings suggest that 'SC Duma 43 ' leaves have antibiosis effect against FAW larvae growth. In contrast, the highest growth index was calculated on 'Rachar', which indicates this cultivar is more suitable for FAW growth. Plant damage scores were statistically not different between cultivars in the field neither under natural nor artificial infestation. Moreover, scores tended to be lower in 'Nyamula' and 'Jowi' at the end of the season under artificial infestation. For successful pest management in low input agriculture, it is desirable to combine more than one measure to keep plant damage at low levels. Therefore, it is necessary to study further how other FAW control options, such as biological control and habitat management could be integrated with maize cultivars with partial resistance to FAW. This study contributes to identify cultivars with partial resistance to FAW that can be used with other management options in Africa.

Supplementary Materials: The following are available online at https:/ / www.mdpi.com/2223-774 7/10/2/392/s1, Figure S1: Design of the field experiment in two blocks (natural infestation-normal letters) and artificial infestation-bold letters) with six cultivars and three replicates, Table S1: Densities of insect predators per plant associated with the studied maize cultivars in the field during two 
seasons, Table S2: Densities of spiders per plant associated with the studied maize cultivars in the field during two seasons.

Author Contributions: Conceptualization, A.T., T.J.A.B., X.C.M., C.A.O.M., and Z.K.; methodology, X.C.M. and Z.K.; validation, A.T., C.A.O.M., Z.K., and T.J.A.B.; writing-original draft preparation, X.C.M.; writing-review and editing, X.C.M., I.S.S., T.J.A.B., A.T., and Z.K.; supervision, Z.K.; project administration, Z.K.; funding acquisition, A.T., C.A.O.M., T.J.A.B., and Z.K. All authors have read and agreed to the published version of the manuscript.

Funding: This work was funded by Biotechnology and Biological Sciences Research Council of the UK with grant BB/R020795/1; the EU FAW-IPM project (FOOD/2018/402-634); the UK's Foreign, Commonwealth \& Development Office (FCDO); the Swedish International Development Cooperation Agency (SIDA); The Swiss Agency for Development and Cooperation (SDC); the Federal Democratic Republic of Ethiopia; and the Government of the Republic of Kenya. The views expressed herein do not necessarily reflect the official opinion of the donors.

Acknowledgments: We are thankful for the professional contribution of Bach. Biol. Derrick Otieno, Bach. Biol. Sheryl Ondasi, the technical support of Amos Gadi, Isaac Odera, and Duncan Simiyu. Thanks to Raphael C. Odhiambo for insect identification. We also thank the statistical advice of Daisy Salifu.

Conflicts of Interest: The funders had no role in the design of the study; in the collection, analyses, or interpretation of data; in the writing of the manuscript, or in the decision to publish the results.

\section{References}

1. Goergen, G.; Kumar, P.L.; Sankung, S.B.; Togola, A.; Tamò, M. First report of outbreaks of the fall armyworm Spodoptera frugiperda (J E Smith) (Lepidoptera, Noctuidae), a new alien invasive pest in West and Central Africa. PLoS ONE 2016, 11, e0165632. [CrossRef]

2. Day, R.; Abrahams, P.; Bateman, M.; Beale, T.; Clottey, V.; Cock, M.; Colmenarez, Y.; Corniani, N.; Early, R.; Godwin, J.; et al. Fall armyworm: Impacts and implications for Africa. Outlooks Pest Manag. 2017, 28, 196-201. [CrossRef]

3. Sharanabassapa; Kalleshwaraswamy, C.M.; Asokan, R.; Swamy, H.M.M.; Maruthi, M.S.; Pavithra, H.B.; Hedge, K.; Navi, S.; Prabhu, S.T.; Goergen, G.E. First report of the Fall armyworm, Spodoptera frugiperda (J E Smith) (Lepidoptera: Noctuidae), an alien invasive pest on maize in India. Pest Manag. Hortic. Syst. 2018, 24, 8.

4. Sun, X.X.; Hu, C.X.; Jia, H.R.; Wu, Q.L.; Shen, X.J.; Jiang, Y.Y.; Wu, K.M. Case study on the first immigration of fall armyworm Spodoptera frugiperda invading into China. J. Integr. Agric. 2019, 3119, 10. [CrossRef]

5. Chhetri, L.B.; Acharya, B. Fall armyworm (Spodoptera frugiperda): A threat to food security for south Asian country: Control and management options: A review. Farm. Manag. 2019, 4, 38-44. [CrossRef]

6. Li, Y.; Wang, Z.; Romeis, J. Managing the Invasive Fall Armyworm through Biotech Crops: A Chinese Perspective. Trends Biotechnol. 2021, 39, 105-107. [CrossRef] [PubMed]

7. Ma, J.; Wang, Y.P.; Wu, M.F.; Gao, B.Y.; Liu, J.; Lee, G.S.; Otuka, A.; Hu, G. High risk of the fall armyworm invading Japan and the Korean Peninsula via overseas migration. J. Appl. Entomol. 2019, 143, 911-920. [CrossRef]

8. Food and Agriculture Organization. Fall Armyworm. 2020. Available online: http://www.fao.org/fall-armyworm/monitoringtools/faw-map/en/ (accessed on 14 August 2020).

9. Baudron, F.; Zaman-Allah, M.A.; Chaipa, I.; Chari, N.; Chinwada, P. Understanding the factors influencing fall armyworm (Spodoptera frugiperda J. E. Smith) damage in African smallholder maize fields and quantifying its impact on yield. A case study in Eastern Zimbabwe. Crop Prot. 2019, 120, 141-150. [CrossRef]

10. Kumela, T.; Simiyu, J.; Sisay, B.; Likhayo, P.; Mendesil, E.; Gohole, L.; Tefera, T. Farmers' knowledge, perceptions, and management practices of the new invasive pest, fall armyworm (Spodoptera frugiperda) in Ethiopia and Kenya. Int. J. Pest Manag. 2019, 65, 1-9. [CrossRef]

11. Mihm, J.A. Insect Resistant Maize-Recent Advances and Utilization; Mihm, J.A., Ed.; CIMMYT: El Batan, Mexico, $1997 ;$ p. 304.

12. Mihm, J.A.; Smith, M.E.; Deutsch, J.A. Development of Open-Pollinated Varieties, Non-Conventional Hybrids and Inbred Lines of Tropical Maize with Resistance to Fall Armyworm, Spodoptera frugiperda (Lepidoptera: Noctuidae), at CIMMYT. Fla. Entomol. 1988, 71, 262-268. [CrossRef]

13. Wiseman, B.R.; Davis, F.M. Plant Resistance to Insects Attacking Corn and Grain Sorghum. Fla. Entomol. 1979, 62, 123-130. Available online: http:/ / www.jstor.org/stable/3495461 (accessed on 12 December 2020). [CrossRef]

14. Host Plant Resistance to Fall Armyworm: Status and Prospects. Prasanna, B P. WTO Meeting. 19 March 2019. Available online: https:/ / www.wto.org/english/tratop_e/sps_e/faw_2_c_prasanna_thematic_session_faw_19march2019.pdf (accessed on 15 April 2019).

15. Odendo, M.; de Groote, H.; Odongo, O.M. Assesment of farmers' preferences and constraints to maize production in the moist mid-altitute zone of Western Kenya. Afr. Crop Sci. Conf. Proc. 2001, 5, 769-775. 
16. Midega, C.A.O.; Pickett, J.A.; Hooper, A.; Pittchar, J.O.; Khan, Z.R. Maize landaraces are less affected by Striga hermonthica relative to hybrids in Western Kenya. Weed Technol. 2016, 30, 21-28. [CrossRef]

17. Tamiru, A.; Bruce, T.J.A.; Midega, C.A.O.; Woodcock, C.M.; Birkett, M.A.; Pickett, J.A.; Khan, Z.R. Oviposition Induced Volatile Emissions from African Smallholder Farmers' Maize Varieties. J. Chem. Ecol. 2012, 38, 231-234. [CrossRef]

18. Stout, M.J. Reevaluating the conceptual framework for applied research on host-plant resistance. Insect Sci. 2013, 20, 263-272. [CrossRef] [PubMed]

19. Gatehouse, J.A. Plant resistance towards insect herbivores: A dynamic interaction. New Phytol. 2002, 156, 145-169. [CrossRef]

20. Withers, T.M. Examining the hierarchy threshold model in a no-choice feeding assay. Entomol. Exp. Appl. 1999, 91, 89-95. [CrossRef]

21. Knolhoff, L.M.; Heckel, D.G. Behavioral assays for studies of host plant choice and adaptation in herbivorous insects. Annu. Rev. Entomol. 2014, 59, 263-278. [CrossRef] [PubMed]

22. Schoonhoven, L.M.; van Loon, J.J.A.; Dicke, M. Insect-Plant Biology, 2nd ed.; Oxford University Press: New York, NY, USA, 2007; p. 421.

23. Yang, G.; Wiseman, B.R.; Isenhour, D.J.; Espelie, K.E. Chemical and ultrastructural analysis of corn cuticular lipids and their effect on feeding by fall armyworm larvae. J. Chem. Ecol. 1993, 19, 2055-2074. [CrossRef]

24. Yang, G.; Espelie, K.E.; Wiseman, B.R.; Isenhour, D.J. Effect of Corn Foliar Cuticular Lipids on the Movement of Fall Armyworm (Lepidoptera: Noctuidae ) Neonate Larvae. Fla. Entomol. 1993, 76, 302-316. [CrossRef]

25. Andama, J.B.; Mujiono, K.; Hojo, Y.; Shinya, T.; Galis, I. Nonglandular silicified trichomes are essential for rice defense against chewing herbivores. Plant Cell Environ. 2020, 43, 2019-2032. [CrossRef] [PubMed]

26. de Fouchier, A.; Sun, X.; Caballero-Vidal, G.; Travaillard, S.; Jacquin-Joly, E.; Montagné, N. Behavioral effect of plant volatiles binding to Spodoptera littoralis larval odorant receptors. Front. Behav. Neurosci. 2018, 12, 264. [CrossRef]

27. Hedin, P.A.; Davis, F.M.; Williams, W.P.; Hicks, R.P.; Fisher, T.H. Hemicellulose is an important leaf-feeding resistant factor in corn to the fall armyworm. J. Chem. Ecol. 1996, 22, 1655-1668. [CrossRef] [PubMed]

28. Bergvinson, D.J.; Arnason, J.T.; Hamilton, R.I.; Mihm, J.A.; Jewell, D.C. Determining leaf toughness and its role in maize resistance to the European corn borer (Lepidoptera: Pyralidae). J. Econ. Entomol. 1994, 87, 1743-1748. [CrossRef]

29. Chen, Y.; Ni, X.; Buntin, G.D. Physiological, nutritional, and biochemical bases of corn resistance to foliage-feeding fall armyworm. J. Chem. Ecol. 2009, 35, 297-306. [CrossRef]

30. Wiseman, B.R.; Davis, F.M.; Williams, W.P.; Widstrom, N.W. Resistance of a maize population, FAWCC(C5), to fall armyworm larvae (Lepidoptera: Noctuidae). Fla. Entomol. 1996, 79, 329-336. [CrossRef]

31. De La Rosa-Cancino, W.; Rojas, J.C.; Cruz-Lopez, L.; Castillo, A.; Malo, E.A. Attraction, feeding preference, and performance of Spodoptera frugiperda larvae (Lepidoptera: Noctuidae) reared on two varieties of maize. Environ. Entomol. 2016, 45, 384-389. [CrossRef]

32. Wiseman, B.R.; Widstrom, N.W. Mechanisms of Resistance in 'Zapalote Chico' Corn Silks to Fall Armyworm (Lepidoptera: Noctuidae) Larvae. J. Econ. Entomol. 1986, 79, 1390-1393. [CrossRef]

33. Sen-Seong, N.G.; Davis, F.M.; Williams, W.P. Survival, Growth, and Reproduction of the Fall Armyworm (Lepidoptera: Noctuidae) as Affected by Resistant Corn Genotypes1. J. Econ. Entomol. 1985, 78, 967-971.

34. Chuang, W.P.; Ray, S.; Acevedo, F.E.; Peiffer, M.; Felton, G.W.; Luthe, D.S. Herbivore cues from the fall armyworm (Spodoptera frugiperda) larvae trigger direct defenses in maize. Mol. Plant Microbe Interact. 2014, 27, 461-470. [CrossRef] [PubMed]

35. Chuang, W.P.; Herde, M.; Ray, S.; Castano-Duque, L.; Howe, G.A.; Luthe, D.S. Caterpillar attack triggers accumulation of the toxic maize protein RIP2. New Phytol. 2014, 201, 928-939. [CrossRef] [PubMed]

36. Hariprasad, K.V.; van Emden, H.F. Mechanisms of partial plant resistance to diamondback moth (Plutella xylostella) in brassicas. Int. J. Pest Manag. 2010, 56, 15-22. [CrossRef]

37. Rojas, J.C.; Kolomiets, M.V.; Bernal, J.S. Nonsensical choices? Fall armyworm moths choose seemingly best or worst hosts for their larvae, but neonate larvae make their own choices. PLoS ONE 2018, 13, e0197628. [CrossRef]

38. Mihm, J.A. Efficient Mass-Rearing and Infestation Techniques to Screen for Host Plant Resistance to Fall Armyworm, Spodoptera Frugiperda; Centro Internacional de Mejoramiento de Maiz y Trigo-CIMMYT, Ed.; CIMMYT: El Batan, Mexico, 1983.

39. Rosenthal, J.P.; Welter, S.C. Tolerance to herbivory by a stemboring caterpillar in architecturally distinct maizes and wild relatives. Oecologia 1995, 102, 146-155. [CrossRef]

40. Ni, X.; Xu, W.; Blanco, M.H.; Williams, W.P. Evaluation of fall armyworm resistance in maize germplasm lines using visual leaf injury rating and predator survey. Insect. Sci. 2014, 21, 541-555. [CrossRef]

41. Sueldo, M.R.; Bruzzone, O.A.; Virla, E.G. Characterization of the earwig, Doru lineare, as a predator of larvae of the fall armyworm, Spodoptera frugiperda: A functional response study. J. Insect. Sci. 2010, 10, 1-10. [CrossRef]

42. van Huis, A. Integrated Pest Management in the Small Farmer's Maize Crop in Nicaragua; H. Veenman \& Zonen, B.V.: Wageningen, The Netherlands, 1981; p. 221.

43. Turlings, T.C.J.; Tumlinson, J.H.; Lewis, W.J. Exploitation of Herbivore-Induced Plant Odors By Host-Seeking Parasitic Wasps. Science 1990, 250, 1251-1253. [CrossRef] [PubMed]

44. Roque-Romero, L.; Cisneros, J.; Rojas, J.C.; Ortiz-Carreon, F.R.; Malo, E.A. Attraction of Chelonus insularis to host and host habitat volatiles during the search of Spodoptera frugiperda eggs. Biol Control 2020, 140. [CrossRef] 
45. Bernasconi Ockroy, M.L.; Turlings, T.C.J.; Edwards, P.J.; Fritzsche-Hoballah, M.E.; Ambrosetti, L.; Bassetti, P.; Dorn, S. Response of natural populations of predators and parasitoids to artificially induced volatile emissions in maize plants (Zea mays L.). Agric. Entomol. 2001, 3, 201-209. [CrossRef]

46. Publication 75A, Guide to Weed Control: Field Crops. Ministry of Agriculture, Food and Rural Affairs Ontario. 2020. Available online: http:/ / www.omafra.gov.on.ca/english/crops/pub75/pub75A/pub75A.pdf (accessed on 18 December 2020).

47. Köhler, A.; Maag, D.; Veyrat, N.; Glauser, G.; Wolfender, J.L.; Turlings, T.C.J.; Erb, M. Within-plant distribution of 1,4-benzoxazin3-ones contributes to herbivore niche differentiation in maize. Plant. Cell Environ. 2015, 38, 1081-1093. [CrossRef]

48. Smith, C.M.; Khan, Z.K.; Pathak, M.D. (Eds.) Techniques for Evaluating Resistance in Crop Plants; Lewis Publishers CRC Press: Boca Raton, FL, USA, 1994; pp. 79, 320.

49. Cheruiyot, D.; Midega, C.A.O.; van den Berg, J.; Pickett, J.A.; Khan, Z.R. Suitability of brachiaria grass as a trap crop for management of Chilo partellus. Entomol. Exp. Appl. 2017, 166, 139-148. [CrossRef] 